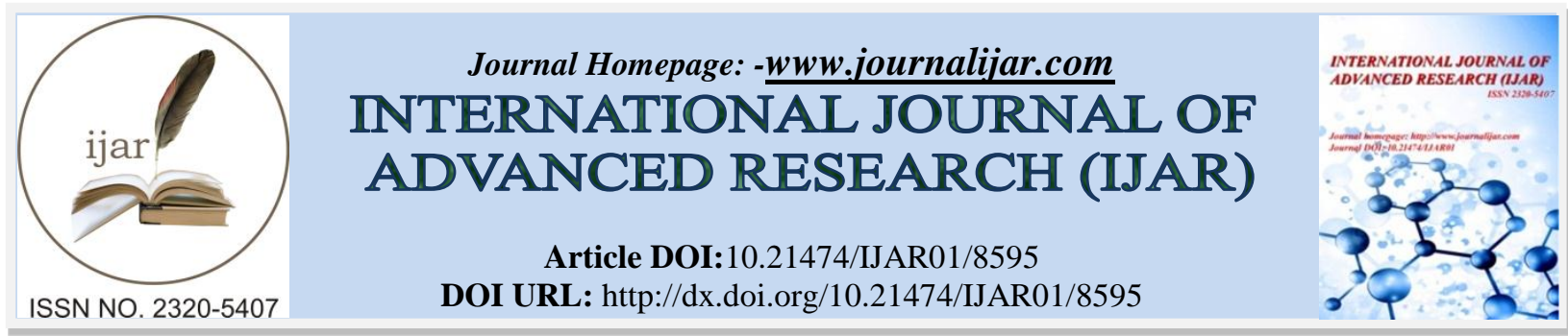

RESEARCH ARTICLE

\title{
IMPACT OF A WASTE DISPOSAL SITE ON GROUNDWATER QUALITY (A CASE STUDY OF OKE- ODO REFUSE DUMPSITE, IWO OSUN STATE SOUTHWESTERN, NIGERIA).
}

\author{
Alagbe O. A ${ }^{1}$, Olutona G.O ${ }^{2}$, Olafisoye E.R ${ }^{3}$, and Olayiwola K.O ${ }^{4}$. \\ 1. Department of Applied Geophysics, Federal University of Technology, Akure - Nigeria. \\ 2. Department of Chemistry and Industrial Chemistry, Bowen University, Iwo - Nigeria. \\ 3. Department of Physical Sciences, Ondo State University of Science and Technology Okitipupa - Nigeria. \\ 4. Department of Remote Sensing and GIS, Federal University of Technology, Akure - Nigeria.
}

\section{Manuscript Info}

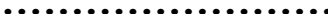

Manuscript History

Received: 02 January 2018

Final Accepted: 04 February 2019

Published: March 2019

Key words:-

Water quality, Contaminants, VLF, VES, Leachate plume, Fracture, Fault, Polution.

\section{Abstract}

Groundwater contamination occurs when urban waste materials, mainly domestic garbage, are disposed of without the appropriate measures imposing a high risk to the underground water resources. Groundwater pollution happens mostly due to percolation of pluvial water and the infiltration of contaminants through the soil. Due to the dangerous effect of the pollution on underground water, this work was carried out. A study of the impact of waste disposal on the groundwater resources around a refuse dumpsite at Oke-odo, Iwo, Osun state, Nigeria was carried out using Very Low Frequency Electromagnetic method (VLFEM) and Vertical Electrical Sounding (VES) of the Schlumberger array. The VLF-EM survey comprised seven profiles with four which run from East to West with 10m inter-station spacing and another three from south to the north to cover the entire study area. A total of two resistivity soundings were also established; one each at the extreme western and eastern region of the waste disposal site.

Hydrochemical analyses were conducted at the peak of the raining season and also during the dry season on five water samples from five hand-dug wells situated at the western and the eastern ends of the study area. These hand-dug wells have depths ranging from 3 to $5 \mathrm{~m}$. Water samples were tested for the concentration level of $\mathrm{NO}_{3}{ }^{-}, \mathrm{PO}_{4}{ }^{3-}, \mathrm{As}, \mathrm{Fe}$ ' $\mathrm{Cu}, \mathrm{Pb}, \mathrm{SO}_{4}{ }^{2-}, \mathrm{Zn}$, and the $\mathrm{pH}$ levels.

The results of the VLF-EM and VES revealed the presence of contaminant plumes which are detected as conductive anomalies mainly of dissolved salts from decayed organic matters. The geoelectric section generated from the VES data revealed that the polluted region has resistivity values as low as $12.0 \Omega \mathrm{m}$ and $40.5 \Omega \mathrm{m}$, and very shallow depths $3.0 \mathrm{~m}$ and $4.0 \mathrm{~m}$ to the anomalous source (contaminant plume). Results of the hydrochemical analyses conducted were compared with the standard guidelines of the World Health Organization (WHO) to ascertain their quality and it was shown that the quality of water in the study area falls below standard.

Copy Right, IJAR, 2019,. All rights reserved. 


\section{Introduction:-}

Groundwater is water located beneath the ground surface in soil pore spaces and in the fractures of rock formations. In any hydrogeological setting, surface water and groundwater are main sources of water. Surface water includes water from rivers, streams and lakes whereas groundwater constitutes water from boreholes, hand-dug wells and springs. Both sources of water are prone to pollution and contamination hence the need for quality assessment (Ngwu and Nwosu, 2009). Groundwater contamination occurs when man-made products such as gasoline, oil, road salts and chemicals get into the groundwater and cause it to become unsafe and unfit for human use. Some of the major sources of these products called contaminants are storage tanks, septic systems, hazardous waste sites, landfills, and the widespread use of road salts, fertilizers, pesticides and other chemicals.

Groundwater contaminants remain one of the main concerns of earth scientists and researchers worldwide because of its adverse effects on both the environment and human health. The accelerated pace of industrial development coupled with uncontrolled growth of the urban population been experience in iwo, the study area has resulted in the increasing production of both solid and liquid residues. Urban waste materials, mainly domestic garbage, are usually disposed of without the appropriate measures imposing a high risk to the underground water resources. Groundwater pollution happens mostly due to percolation of pluvial water and the infiltration of contaminants through the soil. The contaminant fluid results from the decomposition of organic matters that are rich in dissolved salts, containing a substantial amount of polluting substances. When the contaminants liquid reaches the groundwater table, it affects the portability of underground water putting the local community under serious health risk. Contaminants easily found their ways into the groundwater table where the overburden thickness is thin and where the topsoil happens to be a loose soil (sandy or sedimentary soils) and/or through a fracture or fault zones. One of the most frequent demands in metropolitan areas such as Iwo includes the detection of the location and extent of contamination patches in areas as small as an open waste disposal site. In such a context, the integrated use of various geophysical methods provides an important tool for the evaluation and characterization of contaminants generated by urban residues (domestic and/ or industrial). Among the available geophysical methods, electrical resistivity and electromagnetic methods which have been found remarkably suitable for such environmental studies, due to the conductive nature of most contaminants ( Atekwana et al., 2000; Adewuyi and Oladapo, 2011 ).

The hydrochemical study was also employed to evaluate groundwater quality that is suitable for human consumption. Groundwater often consists of seven major chemical elements $\mathrm{Ca}^{2+}, \mathrm{Mg}^{2+}, \mathrm{Cl}^{-}, \mathrm{HCO}_{3}^{-}, \mathrm{Na}^{+}, \mathrm{K}^{+}$and $\mathrm{SO}_{4}{ }^{2-}$, but due to contamination, there may be excess of these chemical elements and also heavy metals and nitrate which are very dangerous to human health may be introduced. In this research work, the combination of electrical resistivity and electromagnetic methods were employed for the investigation of the Oke-Odo open waste disposal site, Iwo Southwestern, Nigeria. Similar methods were applied in the past for landfill characterization and delineation ( Carpenter et al. 1990; Adewuyi and Oladapo, 2011). Geophysical surveys were conducted across the waste disposal site under study to define its geometric characteristics. The obtained images reveal the geometry of the less electrical resistive (more conductive) waste material sitting within a quarried out structure of more electrically resistive (less conductive) bedrock material. Both electrical resistivity method and electromagnetic techniques were used to locate and monitor probable leachate plumes escaping from the waste disposal sites, since the electrical and magnetic conductivities of waste disposal site leachates are usually much higher than that of the natural groundwater.

\section{Water Quality}

Water quality is the physical, chemical and biological characteristics of water. It is a measure of the condition of water relative to the requirements of one or more biotic species and/or to any human need or purpose (Siasu, 2007,Diersing, 2009, Ogunbode et al., 2016). It is most frequently used by reference to a set of standards against which compliance can be assessed. The most common standards used to assess water quality relate to health of ecosystems, safety of human contact and drinking water.

\section{Heavy Metals Pollution In Water}

\section{Common metals and their sources}

Lead: lead gasoline, tire wear, bearing wear, lubricating oil and grease.

Zinc: tire wear, motor oil, grease, break emissions, corrosion of galvanized parts.

Iron: auto body rust and engine parts.

Copper: bearing wear, engine parts and break emissions.

Cadmium: tire wear, fuel burning and batteries. 
Chromium: air conditioning coolants, engine parts and break emissions.

Nickel: lubricating oil, break emissions, diesel fuel and gasoline.

Aluminum: auto body corrosion.

\section{The Effects Of Heavy Metals To Human Health}

Heavy metals are natural components of the Earth's crust. They cannot be degraded or destroyed. To a small extent they enter our bodies via food, drinking water and air. As trace elements, some heavy metals (e.g. copper, selenium, zinc) are essential to maintain the metabolism of the human body. However, at higher concentrations they can lead to poisoning. Heavy metal poisoning could result, for instance, from drinking-water contamination (e.g. lead pipes), high ambient air concentrations near emission sources. Heavy metals are dangerous because they tend to bioaccumulate. Bioaccumulation means an increase in the concentration of a chemical in a biological organism over time, compared to the chemical's concentration in the environment. Compounds accumulate in living things any time they are taken up and stored faster than they are broken down (metabolized) or excreted. Heavy metals can enter a water supply by industrial and consumer waste, or even from acidic rain, breaking down soils and releasing heavy metals into streams, lakes, rivers, and groundwater.

The most pollutants heavy metals are Lead, Cadmium, Copper, Chromium, Selenium and Mercury. Lead in humans, long-term exposure can cause acute or chronic damage to the nervous system on humans. Cadmium in humans, long-term exposure is associated with renal dysfunction. High exposure can lead to obstructive lung disease and has been linked to lung cancer, and damage to human's respiratory systems. Copper is an essential substance to human life, but in high doses it can cause anemia, liver and kidney damage, and stomach and intestinal irritation. Chromium is used in metal alloys and pigments for paints, cement, paper, rubber, and other materials. Low-level exposure can irritate the skin and cause ulceration. Long-term exposure can cause kidney and liver damage, and damage to circulatory and nerve tissue. Chromium often accumulates in aquatic life, adding to the danger of eating fish that may have been exposed to high levels of chromium. Selenium causes damage to the circulatory tissue, and more severe damage to the nervous system. Mercury causes damages to the brain and the central nervous system, causes psychological changes and makes development changes in young children. Normally Mercury is a toxic substance which has no known function in human biochemistry. These chemical parameters play a significant role in classifying and assessing water quality. Chemical classification also throws light on the concentration of various predominant cations, anions and their interrelationships.

\section{Sources And Effects Of Nitrates And Cyanide On Human Health Nitrates:}

The major sources of nitrate include: runoff from fertilizer use; leakage from septic tanks, sewage; erosion of natural deposits. Drinking water that gets contaminated with nitrates can prove fatal especially to infants that drink formula milk as it restricts the amount of oxygen that reaches the brain causing the 'blue baby' syndrome. It is also linked to digestive tract cancers. It causes algae to bloom resulting in eutrophication in surface water.

\section{Cyanide:}

Cyanide is a naturally occurring chemical and is present naturally in many food items including many commonly consumed foods such as cassava, almonds, lima beans and mustard (Franson, 1975). Cyanide may be present in source water or may enter tap water in the distribution system of the individual household. Some of the typical sources of human exposure other than food or drinking water include:

1. industrial such as mining operations, fumigation, metal treatment, steel making, electronics, plastics, dyes, pharmaceutical manufacturing and metal processing,

2. fires (e.g., polyurethane foam, wool, nylon and tobacco),

3. consumer products such as nail glue remover and

4. drugs such as nitroprusside and nitriles (Franson, 1975, Siasu, 2007).

High-doses of cyanide inhibit cellular enzymes resulting in histotoxic hypoxia. The central nervous system (CNS) effects include demyelinating lesions of the brain and a parkinsonian-like encephalopathy . The heart is also sensitive to cyanide induced hypoxia (U.S. EPA, 1973).

Location, climate, and geology of the study area

The study area is located in southwestern, Nigeria between latitude $07^{0} 36^{\prime} 30.5^{\prime \prime}$ and $07^{0} 36^{\prime} 36.3^{\prime \prime}$ north and between longitude $004^{0} 12^{\prime} 02.7^{\prime \prime}$ and $004^{0} 12^{\prime} 06.6^{\prime \prime}$ east (Fig. 1), and the site was presumed have existed for over twenty 
years. It overlies the western upland region of the Nigeria highland plateaux with average altitude between $1000 \mathrm{~m}$ and $1500 \mathrm{~m}$ above mean sea level (Akinloye, et al. 2002). The drainage type is intrinsically dendrites.

Locally, Iwo area experiences tropical rainfall which dominates most of southwestern part of Nigeria and the area has two distinct seasons, the wet season usually between March and October, and the dry season which falls between November and February every year. The annual rainfall for the study area is $1247 \mathrm{~mm}$, but the amount varies from $1016 \mathrm{~mm}$ to $1524 \mathrm{~mm}$, and is almost entirely concentrated in the wet season. The study area falls within the guinea savannah belt of Nigeria but human activities such as exploitation are gradually changing the vegetation to that of Sudan savannah.

The geology of this area consists of Precambrian rocks that are typical for the basement complex of Nigeria (Rahaman, 1976). The major rock associated with Iwo area form part of the Proterozoic schist belts of Nigeria, which are predominantly, developed in the western half of the country. In terms of structural features, lithology and mineralization, the schist belts show considerable similarities to the Achaean Green Stone belts. However, the latter usually contain much larger proportions of mafic and ultra mafic bodies and assemblages of lower metamorphic grade (Rahaman, 1976).

The gneiss complex which underlies the northern and southern part of the Iwo district comprises a considerable broader area of outcrops. Locally, the rock sequence composes of basically weathered quartzite and older granites. The minerals found in this area constitute mostly amphibolites, amphibole schist, meta ultra mafites and meta pelites. Extensive psammitic units with minor meta pelite can also be found. These consist of quartzites and quartz schist. All these assemblages are associated with migmatitic gneisses and are cut by a variety of granitic bodies ( Rahaman, 1976).

The rocks of the Iwo district may be broadly grouped into gneiss-migmatite complex, mafic-ultra mafic suite (or amphibolite complex), meta sedimentary assemblages and intrusive suite of granitic rocks. A variety of minor rock types are also related to these units. The gneiss-migmatite complex comprises migmatic and granitic, calcareous and granulitic rocks. The mafic-ultramafic suite is composed mainly of amphibolites, amphibole schist and minor meta ultramafites, made up of anthophillite-tremolite-chlorite and talc schist. The meta sedimentary assemblages, chiefly meta pelites and psammitic units are found as quartzites and quartz schist.

The intrusive suite consists essentially of Pan African (c.600Ma) Granitic units. The minor rocks include garnetquartz-chlorite bodies, biotites-garnet rock, syenitic bodies, and dolerites ( Folami, 1992; Rahaman, 1976).

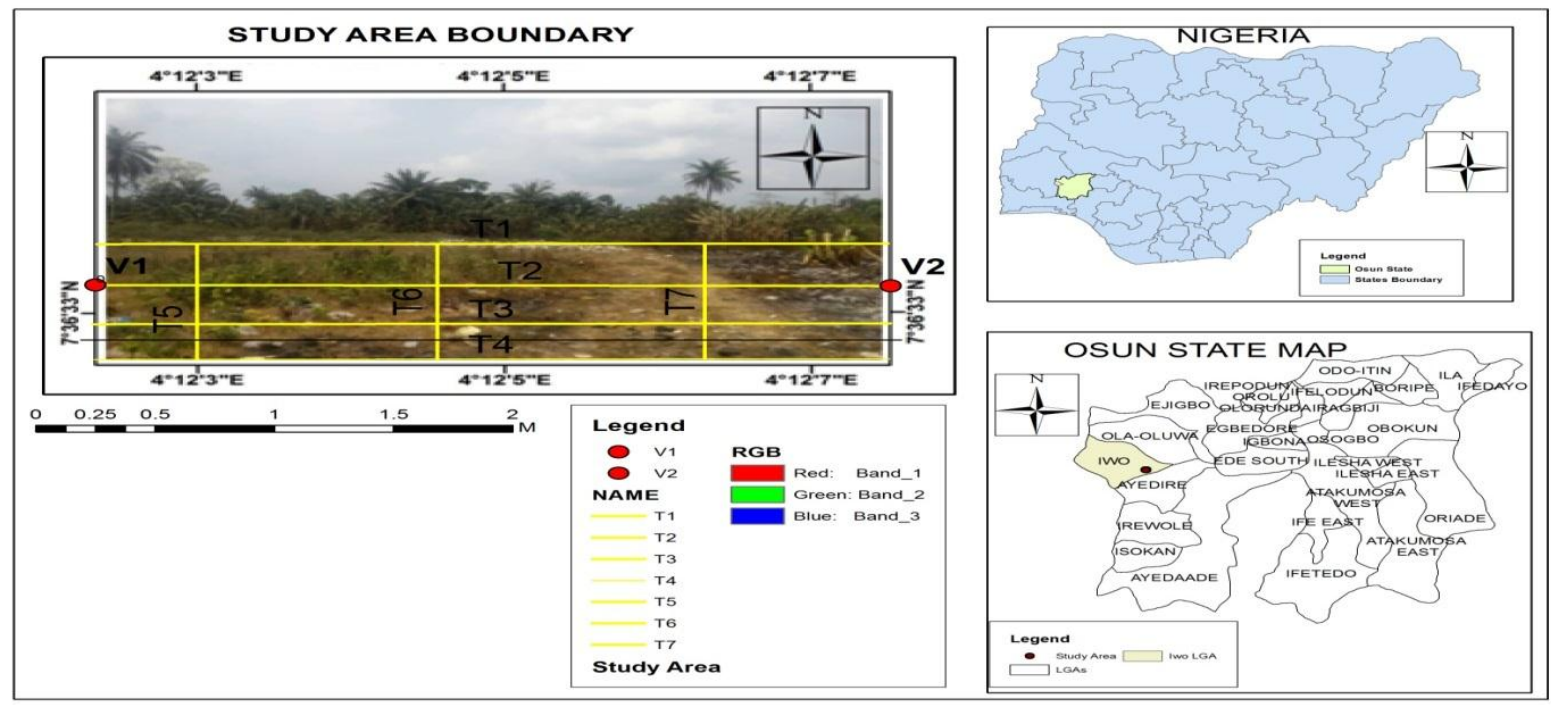

Fig 1:-Showing map of Nigeria showing Osun state, map of Osun state showing Iwo and a figure showing the study site. 


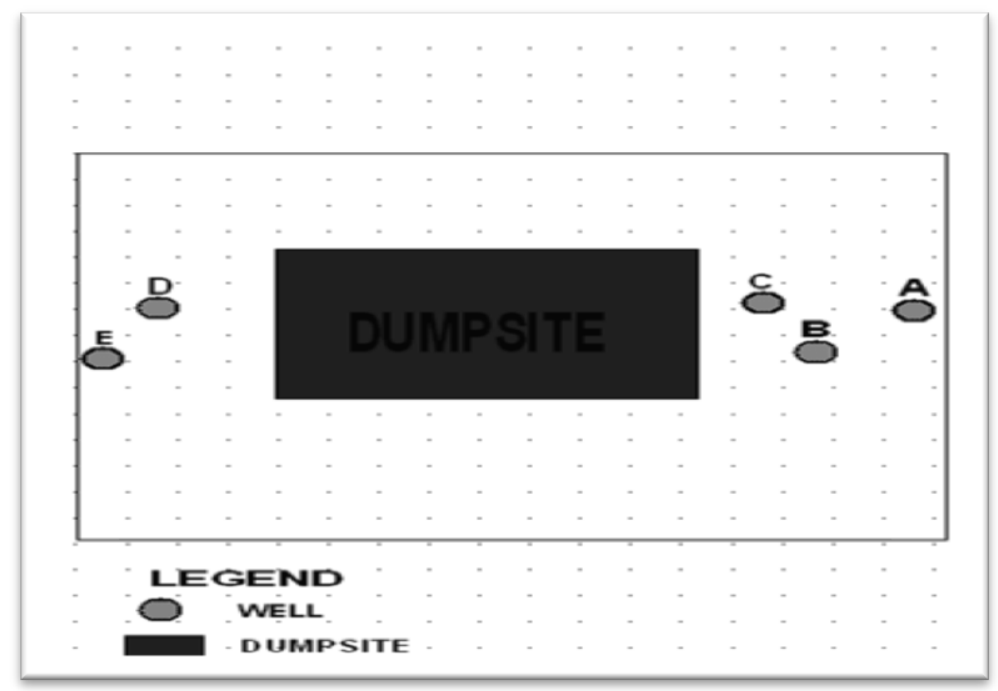

Fig 2:-Showing the Location of Wells Around the Dumpsite.

\section{Methodology:-}

Two methods of investigation were used in this research work. The geophysical technique and hydrochemical analysis.

\section{Geophysical technique}

The investigation was carried out using two geophysical techniques which include electromagnetic (VLF-EM) and electrical resistivity method.

VLF-EM measurements were carried out to study the area in order to track dissolved phase plumes associated with other conductive materials (e.g. a refuse dumpsite leachate plume). More commonly, VLF-EM is used to help locate fracture zones containing water that may also act preferentially as pathways for leachate flow. VLF-EM is a continuous wave (frequency domain) electromagnetic technique that uses low frequency radio transmissions as the source. When these intercept a buried conductor, they induce eddy currents that generate a secondary magnetic field concentric around the source. Seven Very Low Frequency (VLF-EM) profiles were established using a 10m interstation spacing. The filtered real values obtained were plotted against distance measured in metres to obtain conductivity curves for the study area.

Two electrical soundings were carried out at the extreme eastern and western ends of the waste disposal site to resolve the depth of contamination. The electrical resistivity method involved applying the Vertical Electric Sounding method of Schlumberger electrode configuration to delineate vertically the anomalous zones and to identify the degree of contamination. The application of VES technique in electrical resistivity survey requires the computation of apparent resistivity using the resistance $\mathrm{R}$ measured and geometric factors $\mathrm{K}$ of the appropriate electrode array employed. This was achieved using the mathematical expression

$\rho=\frac{\pi L^{2}}{2 l}\left(\frac{\Delta V}{I}\right)$, for Schlumberger electrode spacing.

The apparent resistivity values obtained were plotted against the current electrode separation for each VES point to obtain the resistivity curve types reflective of the subsurface geology for the area.

\section{Hydrochemical analysis}

Two hydrochemical analyses were conducted; one was done at the peak of raining season while the other one was carried out during dry season to have a detailed knowledge of the quality of groundwater in the research area.

\section{Collection of Water samples}

Water samples were collected from five wells close to the dumpsite (Fig. 2) in order to assess the contamination status of the water. The samples were done with plastic bucket and collected over a $2 \mathrm{~mL}$ plastic container. Prior to sampling, all the plastic bottle and glassware were washed with liquid detergents, rinsed with tap water and soaked 
in $10 \% \mathrm{HNO}_{3}$ for 48 hours. They were thereafter rinsed with distill water to preclude trace metal contaminations. The plastic bottles meant for sampling were further rinsed thrice on site with well water being sample.

\section{Determination of Physicochemical parameters}

All chemicals used were AnalaR grade (BDH, England). $\mathrm{pH}$ was measured using a pH Testr meter (Eutech Instruments, Malaysia) after calibrating with standard buffer solutions while conductivity was determined using Testr II dual range meter (Eutech instruments, Malaysia). Sulphate was determined by turbidimetric method (Ademoroti, 1996); phosphate by colorimetric technique and nitrate by ultraviolet screening method (APHA, 1998).

\section{Digestion of water sample}

A $50 \mathrm{~mL}$ aliquot of water sample was transferred into Teflon beaker and $5 \mathrm{~mL}$ of HNO3 was added. This was followed with gentle boiling in a thermostated hot plate in a fume cupboard for about 45 min. The digested water sample was quantitatively transferred into a $50 \mathrm{~mL}$ standard flask and make to mark with distill water. Fromm this an aliquout was taken for AAS analysis.

The digested water samples were analyzed for trace metals using atomic absorption spectrophotometer, Buck 205 model available at International Institute of Tropical Agriculture, Ibadan, Nigeria.

\section{Results And Discussion:-}

\section{Very Low Frequency Electomagnetic Method}

The results VLF-EM data interpretation to detect the leachate plumes were presented as VLF electromagnetic profiles (Fig. 3). Seven traverses were established as shown in Fig.1. The length of the traverses ranges between $50 \mathrm{~m}$ and $70 \mathrm{~m}$. The positive peaks along the profiles in each of the traverses is an indicative of conductive or weak zone (fault or fracture) within the study area and these were considered as pathways for the contaminants to reach the groundwater.

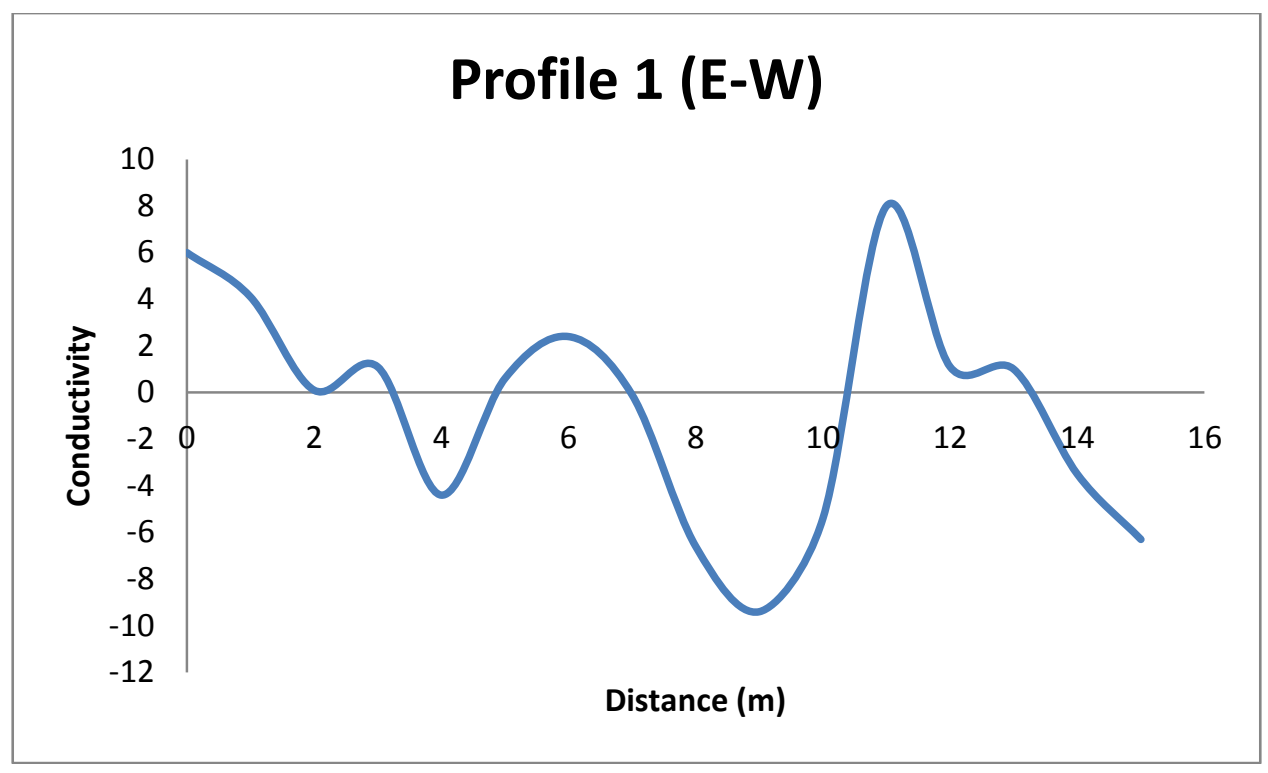



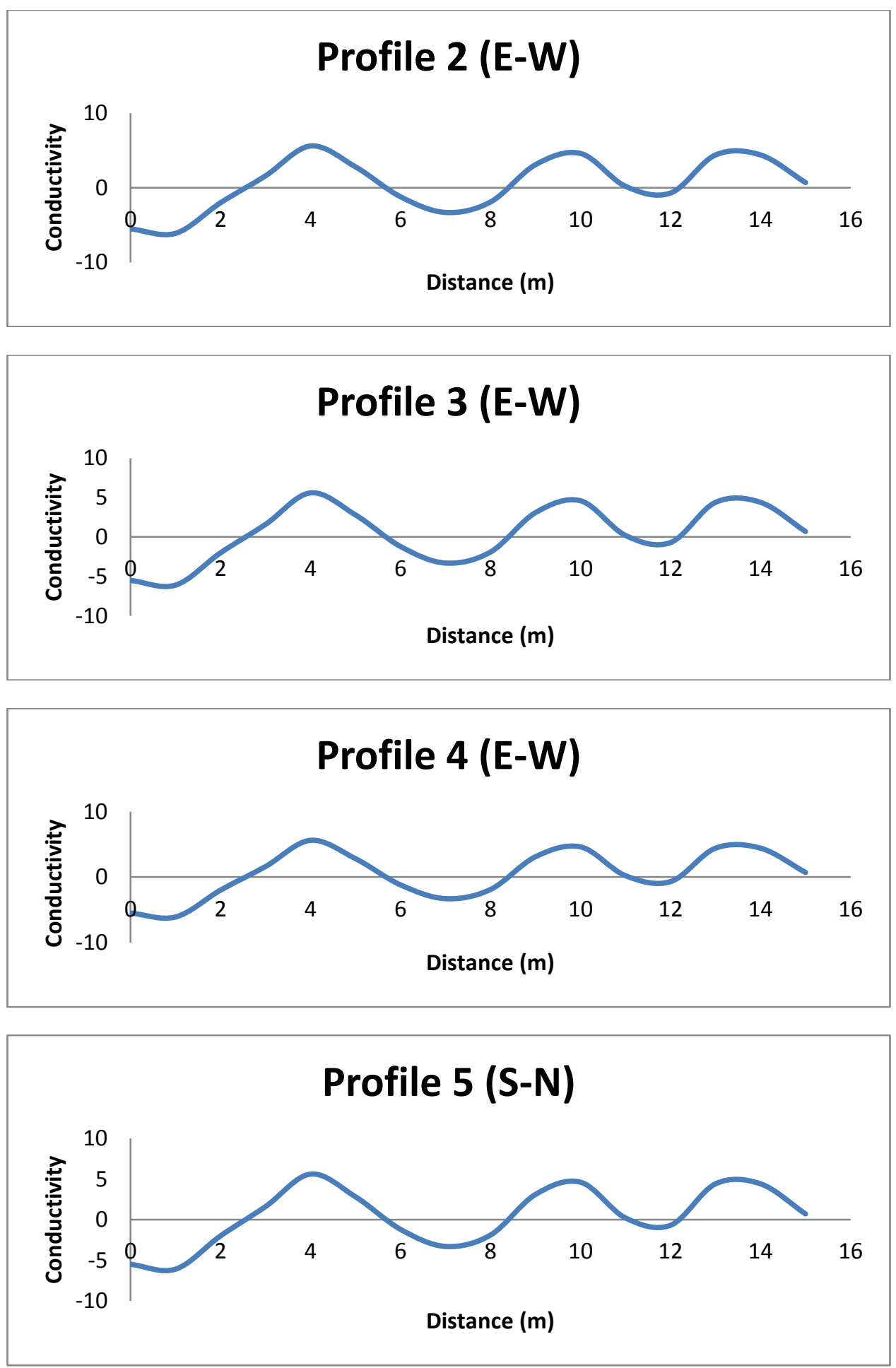

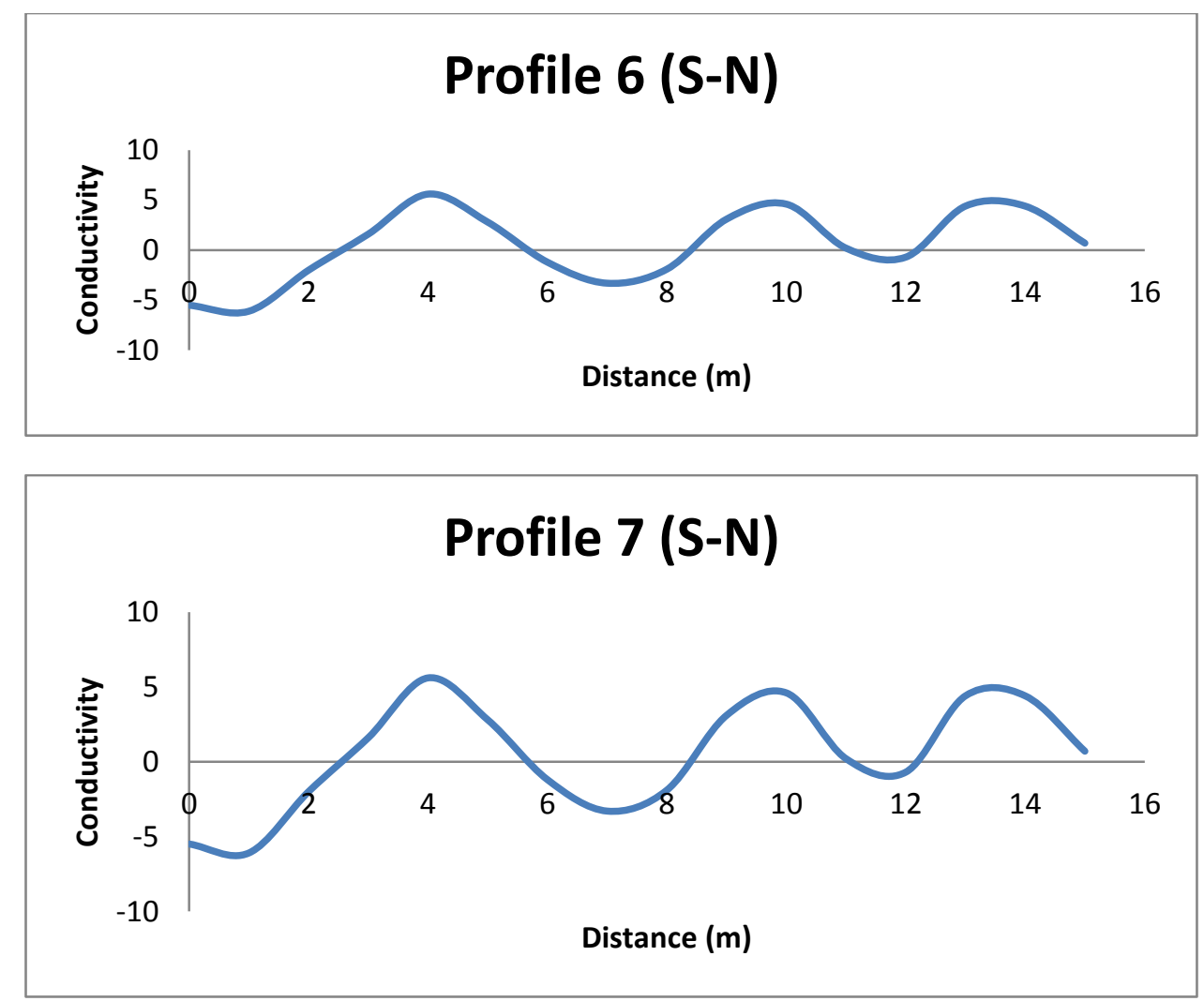

Fig 3(Profiles 1-7):-Showing Filtered Real versus Distance (m)

\section{Vertical Elecrical Sounding Method:-}

The inspection of the sounding curves revealed the different geoelectric layers in terms of their resistivities and depths in the study area. A total of three geoelectric layers were delineated reflecting lithological variations with depth. The nature of the curve types suggests that the measured resistivities vary with depth of investigation in the study site. A depth ranging between 3.0 to $4.0 \mathrm{~m}$ was probed as revealed by the VES curve.

Figures 4 and 5 showed VES 1 and VES 2 with three (3) geoelectric layers. These consist of topsoil, sand and probably clay with varying resistivities and thickness.

The topsoil is characterized by resistivity values ranging from 37.4 to $133.4 \Omega m$ and layer thickness of 1.0 to $1.6 \mathrm{~m}$.

The second layer represent sand with resistivity ranging from 12.0 to $40.5 \Omega \mathrm{m}$ and thickness of 1.4 to $3.0 \mathrm{~m}$. These layers showed a very low resistivity values and are zones of probable risks to groundwater contamination because these low values indicate leachate contaminant plume.

The last layer (third layer) of VES 1 Figure 4, indicate clay of resistivity value $2074.4 \Omega \mathrm{m}$. This high resistivity value is an indication that the area is not contaminated. The last layer of VES 2, figure 5 is probably sand, laterite or weathered clay with a resistivity value of $328.6 \Omega \mathrm{m}$, with this low resistivity value the layer is likely to be contaminated.

The geoelectric section (Figure 6) generated from the VES data obtained from the study site showed the leachate effect been mapped out ( pink colour code) in the region with relatively low resistivity 12.0 to $40.5 \Omega \mathrm{m}$. The low resistivity variations are an indicative of degree of decomposition of the refuse materials and are indications of saturated zones with the migration of leachate into the subsurface starting from the ground surface. The strike lines showed that the basement rock at that zone is fractured, an indication that the water table in this area may have been contaminated as could be seen with a low resistivity value of $328.6 \Omega m$. 
The high porosity and permeability of sandy soil coupled with the thin overburden thickness may have resulted to the unimpeded transport of leachate from the dumpsite to the subsurface, especially into the second layer which served as an aquifer on the research site from which virtually all the hand dug wells in the area obtained their water.

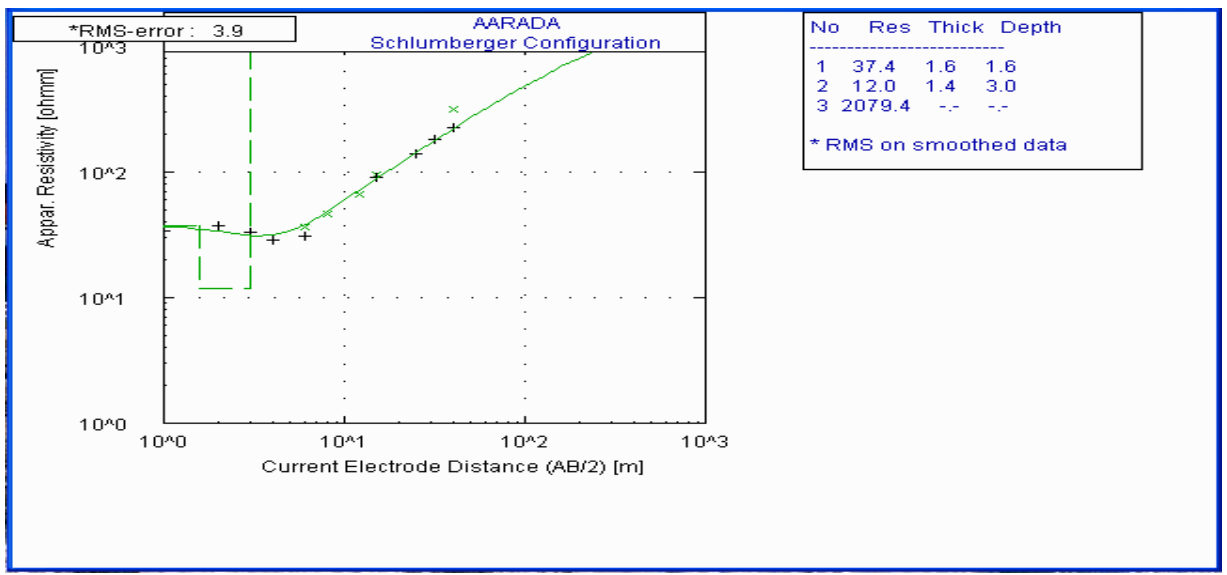

Fig 4:-Showing VES 1

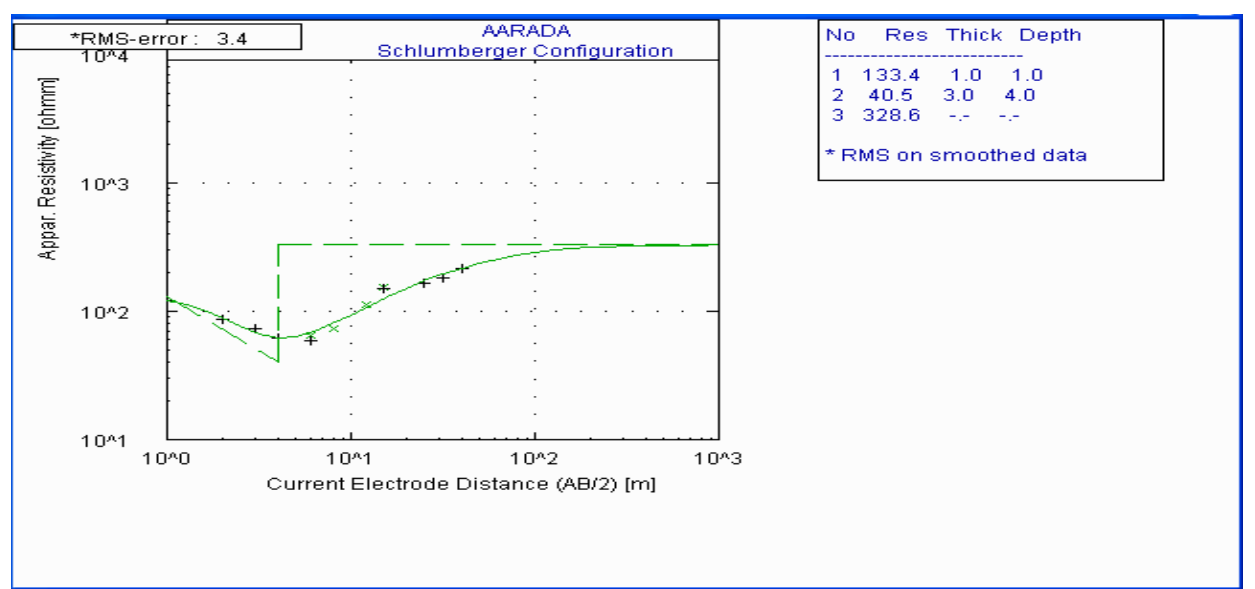

Fig 5:-Showing VES 2

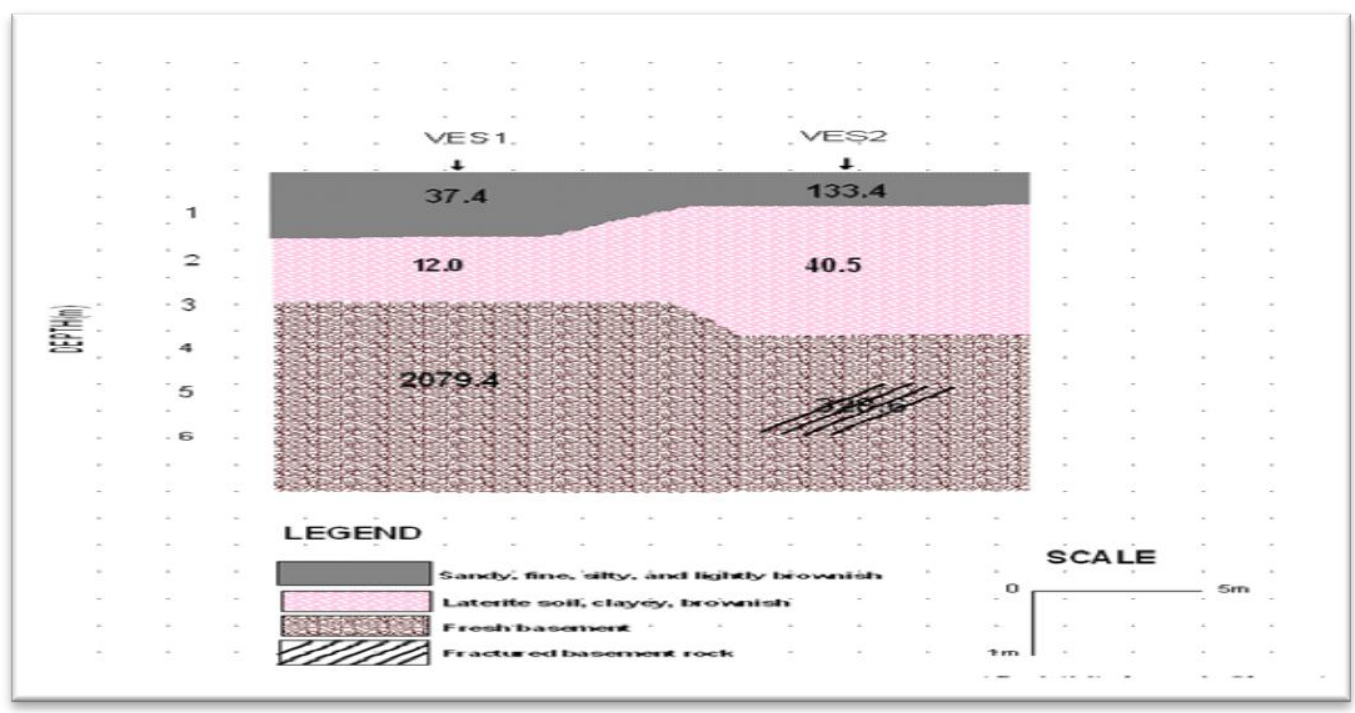

Figure 6:-Showing Geoelectric Section of the Study Area 


\section{Hydrochemical Analysis}

It was observed that the groundwater in the second layer at the dumpsite is polluted among other things because of its high conductivity value. The breakdown of excess organic matters in waste dump does not only consume energy but also release a variety of compounds into the groundwater which can travel kilometers in more permeable environment like in the study site among them nitrate, phosphates, sulphates (Franson, 1975, Ugwu and Nwosu 2009). To confirm this, water samples were taken from five hand dug wells within the dumpsite (Fig. 2), whose distances ranges between $5 \mathrm{~m}$ to $10 \mathrm{~m}$ from the dumpsite and analysed in the laboratory, and the results of the analysis was compared with the World Health Organization (WHO) standard for drinking water as presented in tables 1 and 2. Observations from the two tables show that $\mathrm{pH}$ is normal, and all other physic-chemical parameters were below the permissible level in concentration when compared with the WHO standard. Conductivity is relatively high but still below the permissible level. The nutrients were all below the WHO limit but the nitrate concentration was so high when compared with other anion studied. RADWQ (2010) reported that though ground water in Nigeria is better than surface water in terms of health criteria but most of the ground water is corrosive, and some areas have iron, nitrate and fluoride concentration above the WHO limits for drinking water.

Three of the trace metal analysed ( $\mathrm{Fe}, \mathrm{Pb}$ and $\mathrm{As})$ were higher in concentration when compared with WHO limit while $\mathrm{Zn}$ and $\mathrm{Cu}$ were below the recommended standard limit. The conductivity is high confirming the results obtained from the VLF and VES. Most of the hand dug wells in the study site hardly exceeds 4m. From VES model ( Fig. 4 and 5) it is crystal clear that any good hand dug well for a portable drinking water should exceed $6 \mathrm{~m}$. It was also observed from the hydrochemical analysis (Tables 1 and 2), that contamination level during the raining season was found to be higher than that of the dry season because the migration of pollutants to the underground water from the surface is only possible during the raining season as a result of percolation of rain water.

Table 1:-Result of the hydrochemical analysis carried out on wells at Oke-Odo,Iwo refuse dumpsite during dry season.

\begin{tabular}{|l|l|l|l|l|l|l|}
\hline PARAMETERS & Well A & Well B & Well C & Well D & Well E & $\begin{array}{c}\text { W.H.O. } \\
\text { STANDARD }\end{array}$ \\
\hline $\begin{array}{l}\text { DEPTH OF } \\
\text { WELLS }(\mathrm{m})\end{array}$ & 4 & 3 & 3 & 3.5 & 3.5 & \\
\hline $\mathrm{pH}$ & 7.5 & 7.5 & 7.5 & 7.4 & 7.4 & $6.8-8.5$ \\
\hline $\mathrm{Pb}^{2+}(\mathrm{mg} / \mathrm{L})$ & 0.04 & 0.045 & 0.05 & 0.05 & 0.05 & 0.01 \\
\hline $\mathrm{Fe}^{2+}(\mathrm{mg} / \mathrm{L})$ & 2.90 & 2.93 & 2.93 & 2.06 & 2.05 & 0.3 \\
\hline $\mathrm{Cu}^{2+}(\mathrm{mg} / \mathrm{L})$ & 0.50 & 0.51 & 0.51 & 0.29 & 0.30 & 2.0 \\
\hline $\left.\mathrm{As}^{2+} \mathrm{mg} / \mathrm{L}\right)$ & 0.001 & 0.002 & 0.003 & 0.04 & 0.03 & 0.01 \\
\hline $\mathrm{Zn}^{2+}(\mathrm{mg} / \mathrm{L})$ & 1.30 & 1.4 & 1.61 & 2.20 & 2.10 & 5.0 \\
\hline $\mathrm{NO}_{3}{ }^{2-}(\mathrm{mg} / \mathrm{L})$ & 11.90 & 11.95 & 12.07 & 20.58 & 19.75 & 10 \\
\hline $\mathrm{SO}_{4}{ }^{2-}(\mathrm{mg} / \mathrm{L})$ & 2.80 & 2.87 & 2.97 & 3.22 & 3.18 & 250 \\
\hline $\mathrm{PO}_{4}{ }^{3-}(\mathrm{mg} / \mathrm{L})$ & 2.07 & 2.08 & 2.10 & 2.14 & 2.12 & 50 \\
\hline $\mathrm{Conductivity}(\mu \mathrm{S} / \mathrm{cm})^{585}$ & 588 & 590 & 590 & 590 & 1200 \\
\hline
\end{tabular}

Table 2:-Result of the hydrochemical analysis carried out on wells at Oke-Odo,Iwo refuse dumpsite during raining season.

\begin{tabular}{|l|l|l|l|l|l|l|}
\hline PARAMETERS & Well A & Well B & Well C & Well D & Well E & $\begin{array}{l}\text { W.H.O. } \\
\text { STANDARD }\end{array}$ \\
\hline $\begin{array}{l}\text { DEPTH OF } \\
\text { WELLS }(\mathrm{m})\end{array}$ & 4 & 3 & 3 & 3.5 & 3.5 & \\
\hline $\mathrm{pH}$ & 6.5 & 6.5 & 6.5 & 6.4 & 6.4 & $6.8-8.5$ \\
\hline $\mathrm{Pb}^{2+}(\mathrm{mg} / \mathrm{L})$ & 0.1 & 0.11 & 0.13 & 0.13 & 0.13 & 0.01 \\
\hline $\mathrm{Fe}^{2+}(\mathrm{mg} / \mathrm{L})$ & 7.35 & 7.35 & 7.33 & 4.22 & 4.20 & 0.3 \\
\hline $\mathrm{Cu}^{2+}(\mathrm{mg} / \mathrm{L})$ & 1.33 & 1.30 & 1.28 & 0.73 & 0.75 & 2.0 \\
\hline $\mathrm{As}^{(\mathrm{mg} / \mathrm{L})}$ & 0.003 & 0.005 & 0.008 & 0.1 & 0.08 & 0.01 \\
\hline $\mathrm{Zn}^{2+}(\mathrm{mg} / \mathrm{L})$ & 3.9 & 4.2 & 4.83 & 6.60 & 6.30 & 5.0 \\
\hline $\mathrm{NO}_{3}{ }^{-}(\mathrm{mg} / \mathrm{L})$ & 29.75 & 29.88 & 30.18 & 51.45 & 49.34 & 10 \\
\hline $\mathrm{SO}_{4}{ }^{2-}(\mathrm{mg} / \mathrm{L})$ & 7.0 & 7.18 & 7.43 & 8.05 & 8.0 & 250 \\
\hline $\mathrm{PO}_{4}{ }^{3-}(\mathrm{mg} / \mathrm{L})$ & 5.18 & 5.2 & 5.3 & 5.4 & 5.3 & 50 \\
\hline & & & & & & \\
\hline
\end{tabular}




\begin{tabular}{|l|l|l|l|l|l|l|}
\hline Conductivity $(\mu \mathrm{S} / \mathrm{cm})$ & 945 & 960 & 1000 & 1000 & 1000 & 1200 \\
\hline
\end{tabular}

\section{Conclusion:-}

The integration of electrical resistivity and electromagnetic (VLF-EM) methods was used in this study work to investigate a dumpsite facility. The results of the VLF-EM survey revealed the locations and variation extent of the contamination patches on the site. The VLF-EM curves depict the geometry of the leachate plumes inside the waste disposal site as conductive anomalies.

The results of VES 1 and VES 2 give the values of contamination zones as low as $12.0 \Omega \mathrm{m}$ and $40.5 \Omega \mathrm{m}$ terminating at a depth of $4 \mathrm{~m}$. The measurement of the depths of the hand dug wells in the area varied from $3 \mathrm{~m}$ to $4 \mathrm{~m}$ showing that most of the wells were shallow and therefore prone to contamination due high porosity and permeability of sandy soil and loose topsoil of the study site. The outcome of the hydrochemical analysis conducted on the water samples obtained from the hand dug wells in the area further confirmed this. The results were compared with the standard guidelines of the World Health Organization (WHO, 2011) to ascertain their quality and it was shown that the quality of water in the research area falls below standard. Also since the degree of contamination during raining season is higher than that of dry season, we infer that the contaminants are not actually migrating from the host rocks which act as aquifers but from the decayed organic materials on the surface. Therefore if the cost of borehole could not be afforded within the study site, deep-wells with depths not less than $6 \mathrm{~m}$ or more is recommended or suggested.

\section{References:-}

1. Ademoroti CMA (1996) "Standard methods for water and effluent analysis". $1^{\text {st }}$ edition, Foludex Press Ltd., Ibadan, pp 32-36

2. Adewuyi, O.I. and Oladapo, A G (2011): Use of geophysical methods in landfill site: A case study of ilbadan, Southwestern Nigeria. New York Science Journal Vol.4 (10) Pp1-10

3. Akinloye, M. K.; Fadipe, D. O.; Adabanija, M.A. (2002). A Radiometric Mapping of the Ladoke Akintola University Campus, Ogbomoso Southwestern Nigeria. Science Focus 1; 55-61

4. APHA (1998) "Standard methods for the examination of water and waste water", $20^{\text {th }}$ Edition, American Public Health Association, Washington DC, USA, pp 15-20

5. Atekwana E. A., Sauck W. A., Werkema Jr DD (2000): Investigations of geoelectrical signatures at a hydrocarbon contaminated site. J Appl Geophys 44:167-180

6. Carpenter, P.J.; Kaufman, R.S and Price, B.(1990).Use of resistivity soundings to determine landfill structure. Groundwater Vol.28 PP569-575

7. Diersing, Nancy (May 2009). "Water Quality: Frequently Asked Questions".

8. EPA (1973). Handbook for Monitoring Industrial Wastewater. Chapter 8.

9. Folami S.L. (1992) Interpretation of Acromagnetic Anomalies in Iwaraja Area. southwestern Nigeria. Journal of Minning and Geology vol.28 No 2 pp 391-396

10. Franson, Mary Ann (1975). Standard Methods for the Examination of Water and Wastewater 14th ed. Washington, DC: American Public Health Association, American Water Works Association \& Water Pollution Control Federation. ISBN 0-87553-078-8

11. Ogunbode, T.O., Akintunde, E.A. and Akinola,O.T. (2016): Assessment of undergroundwater quality and pollution sources apportionment in a growing urban centrein Osun state southwestern Nigeria. European Journal of Geography, Vol.7, No.3 ,PP 70-84.

12. RADWQ (2007), Rapid Assessment of Drinking Water Quality in the Federal Republic of Nigeria Country Report 2004-2005. WHO and UNICEF, PP79

13. Rahaman M.A. (1976), Review of Basement Geology of southwestern Nigeria, Elizaberthan publishing company, Nigeria pp $41-58$.

14. SiaSu, G.L., 2007. Impact of drinking water sources in close proximity to the Payatas dumpsite, Phillipines. J Public Health, 15: 51-55.

15. Ugwu, S.A. and Nwosu, J . I. (2009). Effect of waste dumps on groundwater in Choba using geophysical method. Journal of Applied Sciences and Environmental Management 13(1), 85-89

16. World Health Organization, WHO, (2011)" Guidelines for drinking water quality" $4^{\text {th }}$ Edition. WHO Press, USA, p 564 